\title{
'er's from off: The Indexicalisation and Enregisterment of Black Country
}

\section{Dialect}

ABSRACT Following Dubois and Horvath (2002), Adams (2009), Beal (2009) and Johnstone (2009) this paper considers conscious use of dialect in writing is an intentional act and can be accounted for through the notion of enregisterment. It does this by way of an exploration of the value of dialect in social and ideological contexts in relation to a regional dialect of British speech, that of the Black Country in the West Midlands region of the UK. The paper begins by providing a summary of recent directions in sociolinguistic research by way of a background against which the remainder of the paper is set. It then gives an overview of the Black Country speech community, including a summary of its distinctive linguistic variables. This description is then used as an external evaluation of the authenticity of written representations of Black Country speech and the items enregistered in writing. Analysis of three written texts taken from three different genres across a time span of thirty years reveals firstly; the extent to which identified linguistic features are drawn upon in each one of the three texts and the extent to which any one is enregisterd across all three. The paper discusses the social and linguistic contexts within which the writing occurs by way of accounting for their enregisterment as markers of identity linked to region and place. It also considers the ways in which the texts juxtapose norms and values of those 'within' the community with those from 'outside' the community in ways that subvert traditional notions of linguistic hierarchy. ${ }^{1}$

\section{INTRODUCTION}


Following Dubois and Horvath (2002) and Adams (2009), Beal (2009) and Johnstone (2009), this paper discusses how conscious use of dialect in writing is an intentional act, and can be accounted for through the notion of enregisterment. It explores the ways in which variability is represented in the writing of a particular speech community, that of the Black Country. The data upon which the paper draws are three written texts taken from different genres and across a time period of some thirty years, from 1968 to 1997 . The texts are analysed to ascertain which region specific linguistic variables are drawn upon, and the extent to which variables occur within and across texts that can be described as enregistered forms of the dialect. The contexts within which linguistic variability appears is also explored as an essential component of enregisterment. The use of dialect in texts of the kind exemplified in this paper often juxtaposes the norms and values of those 'outside' the community - in terms of both social class and geographic distance - with those 'within' it, thereby identifying with a cultural and social normativity which may be at odds with those from 'outside' it. The texts have been chosen as exemplars to illustrate this point, with the focus upon the Black Country dialect itself, rather than on individual features. The first is an extract taken from a written version of a tale told by a chainmaker; the second a letter to a newspaper and the third a roadside sign. What these texts have in common is that they all represent the Black Country dialect in writing but they differ in terms of genre or text type. Taken together, they indicate the extent to which the Black Country dialect permeates the social fabric of the region. Considering features in the context within which they appear also indicates that such dialect use can function in ways that aim to subvert ideologies of social class and linguistic 'correctness', through the use of the very phenomenon which is stigmatised: enregistered forms of the dialect itself. 


\section{INDEXICALITY AND ENREGISTERMENT}

Increasingly, sociolinguists have come to perceive speaking as an act of identity (e.g., Le Page \& Tabouret-Keller 1987; Llamas and Watt 2010). Recent sociolinguistic research is also reconfiguring earlier social and linguistic hierarchies based upon geography and social class (see, e.g., Dubois and Horvath 2002; Coupland 2007; Beal 2009; Johnstone 2009). Eckert (2012) discusses how social studies of linguistic variation can be seen as having happened in three interrelated waves, each one providing the foundations for the wave that followed. The first wave began with Labov's 1966 seminal work, The Social Stratification of English in New York City. His study and others like it used survey and quantitative methods to examine the relationship between linguistic variability and non-linguistic categories of age, class, ethnicity and sex.

As Eckert points out, such studies taken together developed a 'big picture' of the social spread of sound change, and showed how socioeconomic hierarchy can be mapped onto social space and how change spreads outwards from a locally-based working class. Such studies laid the ground for second wave variationist studies, characterised by ethnographic research methods to provide more fine grained local meanings that complemented the more abstract, first wave non-linguistic, demographic variables or categories, such as Milroy's 1987 research on social networks in Belfast, Northern Ireland. Although first and second wave studies differ in their empirical basis, the focus of research is largely the same, in that both concentrate on analysing linguistic features largely for their role in defining local or regional dialect features. Recently, Third wave studies such as those, for example, undertaken by Eckert (2012) and Coupland (2009), focus upon the social meaning of 
styles in ways that allow for linguistic variables to be studied within layered, rather than single, communities. Third wave studies then, point to a shift towards considering the linguistic properties of not only what is spoken, but also the context within which speech occurs, and of the social meaning of variability. The challenge for sociolinguists then, lies in accounting for the fact that 'who we are' cannot be accounted for wholly in terms of 'where we are from' geographically or to which social class we belong.

Two key concepts which underpin some recent sociolinguistic research are those of indexicality and enregisterment. Indexicality shows how the relationship between categories and concepts on a macro-sociological plane translate or manifest themselves in everyday exchanges between individuals. Silverstein's work (1976, 1993) among others, has been particularly influential in this area. His work echoes Labov's taxonomy of the different kinds of social meanings linguistic variables can carry (Labov 1972: 178-80). Silverstein's notion of orders of indexicality build upon Labov's indicator/marker/stereotype taxonomy, in that the contexts within which indexicality is marked is as important as the linguistic variables themselves. Indexicality can be shown to be of three different kinds or orders. Johnstone, Andrews and Danielson (2006) discuss how Silverstein's first order indexicality is similar to Labov's notion of an indicator, and shows how a variable feature is an indicator of group membership of which speakers themselves are unaware. In a prestandardisation phase, as identified by Labov (1972), speakers are generally unaware of variables which mark or indicate them as a member of a particular group. First order indexicality then, refers to the way in which the frequency of a regional variant correlates with being from a region or place. For example, /aw/ monophtongization 
correlates with being a Pittsburgher from Pittsburgh or $/ \mathrm{t} /$ for $/$ th/ is widely recognized as denoting Newfoundland (Clarke, 2010). People who are socially nonmobile in dense, multiplex social networks, do not notice these correlations, since 'everyone speaks that way'. First order indexicality is followed by second order indexicality, where variation becomes a marker that indicates how speakers use variants in different social contexts. Once identified, such features or variables come to be correlated with and 'mark' a specific sociodemographic identity, be it region or social class for example, by cultural outsiders such as a linguist.

The frequency of particular regional variants can be correlated with being from for example, southwestern Pennsylvania, Newfoundland or any other feature of dialect with being working class and in most instances, with being male. Markers in turn give way to a Labovian stereotype, where a specific variable feature becomes the topic of overt social comment by outsiders. Second order indexicality may give way to third order indexiciality, where people, including those from the 'inside' such as 'Pittsburgers' or 'Newfoundlanders' in the USA or 'Cockneys' or 'Geordies' in the UK, not only have become conscious of features marked out as regional, but deliberately draw upon distinct linguistic variables in ways that show that every place is linguistically variant. Specific regional forms are then enregistered (for example Pittsburghese /aw/) to mark a sense of place identity such as Pittsburgh dislocated from social immobility characteristic of first order indexicality. Enregistered forms are thus drawn from highly codified lists to perform local identity, often in comic, mocking, ironic or semiserious ways. This paper then, exemplifies and applies the concept of indexicality through the consideration of how writers self-consciously and deliberately enregister specific linguistic features as being those of the Black Country. 
It also discusses how by so doing, such writers deliberately and self-consciously set themselves apart from other speech communities. In relation to enregisterment, Adams states that:

There is much to admire about theories of enregisterment as a means to exploring the value of dialect in social and ideological context. The relationship enregisterment constructs between theory and detail is especially valuable. The theory has immediate explanatory value and is grounded in the experience of language, not only by speakers, nor only within a community, but also by a community in contact with outsiders... I especially like the way enregisterment, as an analytical approach to dialect, synthesizes history (including current history), material culture, linguistic fieldwork, folk linguistics/perceptual dialectology, discourse, style, phonology, lexis, syntax - in fact, nearly every aspect of American speech and nearly every approach to studying it (2009:116)

Structure and agency also come into play when one considers the conscious use of dialect in writing which can be seen as an act of indexing identity through the enregistering of specific linguistic variables. This is particularly so if it is used by a writer who is a legitimate speaker of the dialect.

\section{USING DIALECT IN WRITING}

An important issue to be taken into account when considering modern texts written in dialect, is that variational use is popularly perceived as standing in opposition to writing in standard English. Dubois and Horvath (2002) among others, have pointed out that standardisation of a written version of English homogenised much of the 
linguistic variation evident in speech through which a speakers' background can be identified. Beal (2006:531) has also pointed out that the representation of speech in writing becomes an issue once a language has been standardised, and one dialect thus becomes a primary norm agiants which all spelling is judged. Thus, authorised dictionaries of standard English regulate spelling and orthography in English according to primary norms, whilst writing in dialect, including dialect dictionaries, accords to secondary, unregulated ones.

Jaffe (2000) has called attention to the fact that orthography is a tool of abstandssprache: that is, language by distance. One major way in which variation from standard English ${ }^{2}$ (which is, after all, itself a dialect), is indicated through respellings. Re-spellings in dialect serve to highlight the abstand: that is, the distance between representation of a dialect and the reference variety which serves as the norm. As a result, whether or not such distance reflects negatively or positively upon the dialect and its speakers, depends to a certain degree upon whether the text was written by a speaker of the dialect, and thus an 'insider', or whether the view of the dialect is imposed by an 'outsider'. Just as accent does not name a sound pattern alone, but a sound pattern linked to a framework of social identity, so too orthography depicts not only a representation of a sound pattern alone, but also links to a framework of social identity in much the same way. As Jaffe comments, representation of non standard writing in texts written by 'outsiders' to the community of speakers it purports to represent, is thus appropriated by the 'outsider', with no representational control of those who are represented. Such writing, Jaffe notes, reproduces and continues the notion that non standardness links to stigma, and goes a long way towards perpetuating stereotypical, generally negative portrayals of 
social identity. Recent work such as that of Upward and Davidson (2011), Crystal (2012) and Horobin (2013 ) also point to the fact that there is a long tradition, especially in the UK, of associating standards of literacy with morality and standards of behaviour. As Horobin (2013: 5) says, '...the assumption that lies behind such views is that a lack of respect for the rules of spelling, grammar and punctuation is symptomatic of a disrespect for other codes of social and moral behaviour.' Where non standard forms are used in writing by 'insiders', though, writers have total representational control of representation, be it of people, places or behaviour, as the texts considered in this paper show. The three texts discussed below all illustrate writing by 'insiders'. The letter and road sign also illustrate how the contexts within which dialect features deliberately acknowledge the stigma such a use of language attracts but also mocks at the stigma attached to it by 'outgroups'. The intended circulation of texts written in the dialect of the Black Country by its speakers is primarily for an 'in group' and local, rather than national, readerships. The role alignments thus invited on the part of the Black Country reader are more likely to invite alignment with the Black Country 'in-group', and anyone else from beyond the Black Country or 'from off,' alignment with the 'out-group': that is, everyone else.

Dialect writing post standardisation of English is very different from writing in English prior to and during the period of standardisation. Standardisation of English is characterised by primary norms of spelling, grammar and punctuation and reproduced primarily through education (Clark 2001). Thus, writers of dialect texts post standardisation would most likely be literate in standard English themselves, and thus conscious of non-standard features characteristic of the regional dialect they represented in writing. Writing in dialect thus reflects shared pre-standardisation 
speech norms across a regional community rather than those of RP speakers. Consequently, as Beal (2005:532) points out: 'this dependence upon a known or shared 'normal' relationship between sound and spelling makes semiphonetic spelling at times difficult to interpret without prior knowledge of the accent represented'.

Preston (1985) has distinguished between three different kinds of spellings as applied to words or lexical items: allegro speech, eye dialect and dialect re-spelling ${ }^{3}$. The first two categories, allegro speech and eye dialect, describe features that are shared by all dialects but are not at the standard end of the continuum, whilst dialect respelling marks regionally specilaized use. Allegro speech attempts to capture the fact that speech is casual, and not necessarily monitored in the same way as standard English spelling. Such spelling is characteristic of non-standard features shared by other dialects. For example, writing snice 'that's nice', would of 'would have' and gonna 'going to'. Forms which reflect no phonological difference from their standard counterparts are known as eye-dialect. For example, wot for what; sez for says and enuff for enough. Dialect re-spelling attempts to capture regional and social features of pronunciation, and, for the purpose of this paper, include variation in both phonology and morphosyntax such as the Black Country mon 'man', saft 'soft' and yawm 'you are'. The point here is that in using nonstandard spellings to represent either non standardness in general or a specific dialect, many readers will read in stigma regardless of writers' conscious or unconscious motivations or intentions. The analysis of the texts discussed below focuses upon identifying regional re-spellings, since it is from within this category that region specific variation is enregistered. The discussion shows clearly, especially the letter and road sign, that the writers of these texts turn the notion of stigma on its head. It shows how the writers of the texts are 
well aware of the social stigma attached to non standardness, by mocking such stigma through drawing deliberate attention to the use of non standard forms.

When it comes to writing then, it can be said that writers draw on identified linguistically variable features and thus intentionally enregister certain linguistic items as indexical and self reflexive, conscious acts of identity. Furthermore, such writing often challenges established notions of 'correctness' in writing and thereby mocks at the 'correctness' of values often associated with standard English and the English middle classes in ways that are deliberately self-deprecating and ironic.

\section{THE BLACK COUNTRY SPEECH COMMUNITY: AN OVERVIEW}

The Black Country is a relatively small geographical area located in the West Midlands region of England. Today, what were once hamlets, villages and small towns, jostle next to one another in relatively close proximity into what has become a dense, urban sprawl. One reason popularly given for the region's distinctive dialect is its relative geographical isolation. The Black Country is essentially a plateau rising up to 800 feet high without a major river or Roman Road passing through it. There is also no evidence of any Danish invasion, and thus the major historical influence would appear to be Anglo-Saxon, with the area seemingly untouched by Roman occupation. This is apparent by the predominance of place names of Saxon origin, such as Wordsley and Wolverhampton. At the time of the Norman Conquest, the Doomsday Book shows the plateau as being sparsely populated and economically insignificant, a situation that continued throughout the medieval period. Economic activity thus tended to bypass this area, concentrating instead on the river valleys to the north, south and west, or in the nearby booming manufacturing town of Coventry 
(now a city). It was not until the building of canals during the nineteenth century that the area. Throughout the period of the Industrial Revolution, manufacturing in the area included localised, home or community based manufacturing such as chainmaking, alongside factories and mills. Development in the region until well into the twentieth century was relatively slow and the population remained reasonably stable. Until the nineteen sixties, there was never a sudden influx of workers, immigrants or otherwise, who might have significantly altered the character of the area. Similarly, there was little migration out to other areas, as the Black Country generally remained prosperous. By the mid twentieth century however, the reputation of the region was that of a place which was dirty, full of smoke and with generally unpleasant living conditions.

Today, the area is made up of the four boroughs of Dudley, Walsall, Wolverhampton and Sandwell. The boroughs of Dudley and Walsall centre on towns of the same name. Wolverhampton was also a town until 2000 when it was granted city status ${ }^{4}$. Whether or not all of the Wolverhampton borough falls within the Black Country is a matter of much local debate. Sandwell has no town of that name within its borough but various others, of which the largest is West Bromwich, which borders Birmingham but again, this border is imprecise. Exactly where the physical boundaries of the Black Country lie then, is a source of much local dispute. As the Black Country has no physical or political boundaries recognised by its inhabitants, they have little respect for the imposition of human ones such as boroughs. The Black Country is thus more often defined by what it is not than what it is, and primarily in opposition to the neighbouring large city of Birmingham. It is thus a good example of what Anderson (1991) terms the 'imagined community', in that it exists only in the 
minds of its residents, and manifests itself through discursive practices. In Cohen's terms (Cohen 1985:12), a boundary 'encapsulates the identity of a community, and, like the identity of an individual, it is called into being by the exigencies of social interaction'. Within the Black Country today, dialect is often used as one of the main determining factors of whether or not a certain town or village falls within its boundaries. Inhabitants of an area within the Black Country might agree that they share many dialect features with towns which may be relatively far away but which nevertheless lie within its perceived borders, and very little in common with much closer neighbouring towns and cities, especially Birmingham.

The maintenance of local linguistic norms has often been attributed to close-knit social networks associated with working class communities. Thus, as social networks loosen or change, so too, it is argued, does the use of local linguistic norms (see, e.g., Williams \& Kerswill 1999). For example, some people born and brought up in the Black Country might have shifted their social status, and through either education and/or occupation have moved into the middle class from their working class backgrounds; others may have moved geographically as well as socially elsewhere within England or across the world, but may still maintain links with the area and continue to identify with it. The local newspaper, The Black Country Bugle for example, has world wide circulation as does The Black Country Society through its website and associated publications.

Until recently, dialectology has tended to ignore the assumptions, attitudes and beliefs that nonlinguists have about connections between language, space, and place. One branch of dialectology that has sought to redress this balance is that of Perceptual 
Dialectology, a term first coined by Preston in 1981 but re-named by him in 2010 as Folk Dialectology (FD). FD focuses upon what nonlinguists say they understand about linguistic variation, taking account of attitudes and beliefs about variation. The relationship between language and place within such studies is thus more subjective than those undertaken in traditional dialectology, in that people's beliefs about language encompass beliefs about social realities alongside more objective geographic or political facts. FD allows researchers to question the assumptions often made about the close connections between place, language, and identity. Furthermore, research has shown how people in cities view their linguistic landscape in ways that are often different from but sometimes similar to people outside of city limits. Previous research in New York City for example, (Preston 1989), and that of other cites in the United States (e.g. Fridland and Bartlett 2006; Cramer 2010) and others across the globe (e.g. Romanello 2002; Bijvoet and Frauru 2011), has exemplified the ways in which FD can be used to determine how city dwellers view their own way of speaking as well as that of nearby communities.

Anther aspect of the relationship between language and society is that which Preston (2010; 2011) has called 'language regard.' 'Language regard' is used by Preston to cover: ' ...all approaches to the study of non-linguistic belief about and reaction to language use, structure, diversification, history and status, and none of the various approaches that have concerned themselves directly of such matters...' (2011:10). Like FD, Language Regard is becoming increasingly essential to sociolinguists' understanding of the relationship between language and space. Preston also points out that there is nothing in language itself that intrinsically triggers regard. Rather, regard occurs as a result of an association between noticed linguistic features and non 
linguistic caricatures of speakers on the part of the hearer who is not from the same region. Another factor to be taken into consideration in relation to 'language regard' is that identified by Labov in the 1960s of linguistic security and insecurity, where there is a divergence between how people actually speak and their reported selfassessment. This has often led speakers, especially lower middle class women, to 'hypercorrect' their speech, as a symptom of desire for linguistic legitimacy.

Linguistic legitimacy is often represented by the standard form of a language and/or the linguistic usage of socially dominant groups. Some speakers of lower social status have thus been shown to alter their speech to mimic or to approximate that of the dominant group as a way of identifying with them, which often leads to hypercorrection. In the English speaking world, standard forms of English are accorded most linguistic legitimacy and in England, with the corresponding accent of Received Pronunciation (RP). Within the UK, research undertaken in England into the desirability of regional accents and dialects such as Coupland and Bishop's 2007 study, places that of the West Midlands (a general term to include both Birmingham and Black Country accents), to people from outside the region as the least popular and least socially attractive of all English accents. In terms of language regard then, the Black Country dialect in the general public's perception remains at the very bottom of perceived linguistic hierarchy in the UK. However, in terms of linguistic security and insecurity, considering enregistered linguistic forms in the context in which they are written, indicates a high level of linguistic security on the part of Black Country writers who are well aware of the social value accorded to standard English but who nevertheless, choose to write in dialect. 


\section{BLACK COUNTRY DIALECT}

Previously under researched, the Black Country dialect has been the subject of recent academic linguistic description including phonology (Clark 2004); grammar (Higgs 2004); and phonology, grammar and lexis (Manly 1971; Asprey 2008; Clark and Asprey 2013). Higgs points out that the dialect has strong links with Mercian dialects, citing the continuing contemporary use of words that are Anglo Saxon in origin but which have disappeared from standard English, such as myther 'worried', werret 'sigh distressfully', blether 'incoherent talk' and glede, which is a small lump of coal. Another feature which existed up until the early decades of the twentieth century but which is rarely heard today, is the addition of the morpheme en as a plural marker on words such as 'house' or 'ash', making them housen and ashen. Other features, discussed in more detail below, include the use of negative forms of the verbs be, have and $d o$, which resemble Mercian English more closely than their equivalents in standard English. While this may indeed be the case, the claim of continuity with the Mercian dialect of Old English is itself an ideological construct, enregistering Black Country dialect as ancient and authentic.

Clark and Asprey's work shows that many of the most locally distinctive forms in use today exist in the morphology and morphosyntax of the variety as well as in its phonology. Phonologically, regionally variance is marked by diphthongisation in the GOOSE set at [uə] (Clark 2004) and backed variants of the first element of the diphthong in the PRICE set (Wells 1982). Vowel exchange of $/ \mathrm{o} /$ for $/ \mathrm{a} / \mathrm{or} / \mathrm{u} /$ is also prevalent in words such as mon for man and mom for mum (Clark and Asprey 2013). A feature of modern south western dialects of English as identified by Trudgill (1999) among others, also shared by the south eastern dialect of Essex, is that known as 
'pronoun exchange'. That is, the pronouns 'he', 'she', 'we', 'they', can occur as objects as well as subjects of verbs, for example; 'in our own tongue' becomes in we oon tung; 'have never pleased us' becomes 'ave never playzed we. In the Black Country dialect, both the strategy of ablaut negation for modal and support verbs and pronoun exchange exemplified by the use of traditional western Midlands <her> for $3^{\text {rd }}$ person female subject pronoun differ radically from standard English forms, yet are in widespread use, as in 'er's from off' for 'she's from beyond or outside the region'. The negative forms of modal and support verbs (and those support verbs which can also function in main position) are also used. Examples of this are for the verb do where the negative present $I$ do not becomes [dov] and the negative past $I$ did not becomes [dei]. In the same way, the past negative form for the verb be and past negative for the verb have are both [ei], (except in the third person singular, which follows the standard paradigm).

Further distinctive grammatical forms exist in the conjugation of the present tense of the verb be which again differ radically from standard English, and are still in use today. In the present tense of the verb 'be', am is used throughout, apart from the third person singular, which is the same as the standard English 'is'. The first and second person present tense of 'be' pronounced in English as two distinct words, 'I am' and 'you are', are often contracted in speech to form one word, Yam for 'I am'and Yom for 'you are'. Such a feature has led to people from the Black Country being described as yam yams. Originally used as a derogatory term by 'outsiders', it is also becoming appropriated by some members of the Black Country community as a term of endearment. Other grammatical features include the use of ah ay gooen for 'I'm 
not going' in the present continuous tense of 'go'; in the use of the second and third person imperfect past tense of both affirmative and negative forms of the verb 'be' as: you was and he was; I wor, you wor and they wor. Negative verb forms also contract, as in cor 'can't/couldn't'; doh/doe 'don't'; day 'didn't'; who 'won't'; shair 'shan't' and ay 'hasn't'. The same form for negative constructions is used for all persons. In these forms, the negative element has been incorporated within the verb, so that this and the tense are indicated solely by the vowel sounds.

Despite negative public perceptions of the Black Country accent and dialect beyond the region and its community, its use is still very evident amongst the Black Country community itself, in both speech and writing. Little writing in the Black Country dialect by Black Country speakers exists before the 1930s but it was during the 1960s that many of the local, regionally based cultural institutions still thriving today were founded. One is a local newspaper, The Black Country Bugle, which prints articles, poems, short stories and letters to the editor in the Black Country dialect as well as in standard English; another was the founding of the Black Country Society including its quarterly journal, The Black Countryman, devoted to local history and literature which also publishes pieces written in dialect. The Society also prints other publications, including poems, ballads and tales written in dialect or in sttandard English by local writers. Today, this Society has its own website. Vocabulary books began to be written, such as Aynuk's First Waerd Book. In 1975, the Black Country Living Museum was opened in Dudley, to celebrate the region's history and traditions and local historical societies also thrive. 
Just as visitors to Tyneside in the North of England, will find written forms of Geordie dialect in shopping malls such as the Metro Centre (Beal 2000), visitors to the Black Country can pick up selected books of the Bible translated into the Black Country dialect at the Black Country museum, buy volumes of Black Country Stories and download a Black Country Dialect Dictionary. As in parts of the UK and other English speaking countries, dialect words and phrases have been commodified and appear on mugs such as Yow.m Avin a Loff 'you're having a laugh', on t-shirts such as It ay a Canal It's The Cut 'It isn't the canal it's the cut' and Owbinya how have you been' on canvas bags. Continued use of the dialect though goes beyond this, with articles, letters, poems and stories written in dialect appearing regularly in The Black Country Bugle and road users being greeted with notices warning them of road works written in the local dialect, as discussed below. The Black Country dialect then, is very much part of the fabric of the social life within the community.

\section{WRITING IN BLACK COUNTRY DIALECT}

The examples and analysis in this section exemplify ways in which certain dialect features have become enregistered in writing. As Johnstone, Andrus and Danielson (2006), Agha (2007) and Clark (2001 \& 2013) among others have pointed out, speakers and writers notice and attribute meaning to regional variants, shaped mainly, by ideologies linked to social class and notions of correctness. However, writing in dialect does not of itself render the whole dialect enregistered, as enregisterment constitutes a very deliberate decision. Such choice is best considered against the framework of indexiciality summarised above. The focus then, is not upon individual forms that have become enregistered and symbolic of 'Black Country,' but rather of 
the variety itself which signals in-group membership, practices and ideologies. Beal (2000), writing with reference to the Geordie dialect, suggests that the features chosen for written representation of the Geordie dialect are those which are most closely associated with Geordie identity, concluding that Geordie writing is written for Geordies, for 'insiders' and the local community. It is thus a shared code which reinforces solidarity and where humour, in particular, relies upon insider knowledge of this shared code. All this can also be said of the Black Country dialect. As Beal suggests, writing in dialect - both within and outside the context of 'popular writing' - functions as a vehicle for expressing, or indexing, local identity.

The three texts discussed below are given as exemplars of this process over the last thirty years. The first is an extract from a tale written in dialect published in 1968 as part of a collection of stories, the second is a letter written in dialect to the editor of the Black Country Bugle published in 1995 and the third, a roadside sign which appeared in 1997, written in both the Black Country dialect and that of standard English. These examples are analysed as exemplars of three different genres: a written version of an oral tale, a letter to a newspaper, and a roadside sign. Theywere chosen as examples across genres rather than within genres, to ascertain the extent to which all three draw upon and share identified linguistically variable features that can thus be said to be enregistered forms of the dialect. They were also chosen because the texts span a period of thirty years, from the 1960s to the 1990s, during which period ever increasing sections of the population became literate.

One would have thought that since writing is taught as standard English with an underlying ideology of 'correctness' and any non-standard use of English deemed 
'dialect interference' and thus 'incorrect', that the representation of dialect in writing would die out. However, the opposite seems to be the case. Far from dying out, Black Country writers are continuing to write in Black Country dialect in very deliberate ways, enregistering specific features as emblematic or indexical of the regional variety. Moreover, they do so as markers of identification not only with a place and space but also with specific sets of values in ironic, self deprecating ways that signal alternative ideologies. The texts are thus analysed in relation to the extent to which each one draws upon identified regional variables, to show the frequency with which any one of them is used as an index of Black Country-ness and enregistered in writing. It is argued that, given the time span from which the examples are drawn, the more often a given feature occurs within each of these three texts, the more valid is the claim that that such features have become enregistered and index social identities expressed through the Black Country dialect. Analysis then, focuses on dialect respellings linked to the Black Country, since it is these variations which become enregistered as indicative of a specific place, and leaves aside allegro speech and eye dialect whose use is more widespread.

The first example is taken from a tale, The Garrulous Chainmaker, written by T.H. Gough. Gough was a locally well-known businessman, with an accountancy practice in the late nineteenth century in Dudley, a town located in the heart of the Black Country, which still exists today. He had a reputation for honesty, and after the 19141918 war, helped local businessmen who had run into trouble with their income tax, on condition that they confessed to any profiteering that may have gone on. He was more than a successful accountant though Fletcher (1968:10) points out: 'he was a man with a deep sense of humour and a genuine regard for the people of the Black 
Country with whom he worked.' Gough's tale was first published in the 1930s in a local (now defunct) newspaper called The Dudley Herald, and features in an edited collection of Black Country Stories first published by Harold Parson in 1968 by The Black Country Society and reprinted regularly. Parsons Stories are the earliest known examples of writing in Black Country dialect in modern times. As an educated man, Gough would have been familiar with standard English in writing, but chose to write down the tales told to him as they were spoken, which necessitated re-spelling to approximate the spoken word as a means of giving authentic voice to working men's experiences of the time. ${ }^{5}$

The tale of The Garrulous Chainmaker recounts a local chainmaker's experience of ill-health, and his reaction when a series of doctors diagnose the cause of his illness as the amount of beer he drinks, rather than to the sweated labour of his occupation. His recounting of this experience leads him to reminisce into a further re-telling of events that occurred forty years earlier, which ended with the narrator being fined regularly for drunkenness. Finally, the tale ends with the moral that: '...we cor all be tachers an' parsons, sum on us must maeke a bit o' caeble chaien sumtimes'(Gough, 1968:65). That is, we can't all be teachers and parsons, some of us must make a bit of cable chain sometimes. The tale contrasts attitudes and values of the middle class towards the working classes, represented by the doctor as drunks and workshy, as opposed to the working class itself as represented by the chainmaker, who drank beer to quench thirst brought upon by his labour at a time when the sanitariness of drinking water was questionable. The extract below is taken from the middle section of the tale: 
“ These ere doctors, if yo' ay feelin' up to the mark an yo' goo to ask 'em wot's 1 These here doctors, if you aren't feeling up to the mark and you go to ask them what's the matter, the very fust question they askin' yer is ow much beer dun yer drink. 2 the matter, the very first question they ask you is how much beer do you drink.

Well, I doe 'ave a lot considerin' the waerk I does. Wen yo'm makin'

Well, I don't have a lot considering the work I do. When you're making

big kaebles, yo' 'as to 'ave sum beer, else yo'd drap jed. Yo'm swettin'

big cables, you have to have some beer, else you'd drop dead. You're sweating most on it out on yer.

Most of it out of yourself.

'I've on'y bin on the Staet onst, an' wen I was took bad I went to see

I've only been on the State once, and when I was taken bad I went to see

ode Doctor Tibbetts at Craedley. A good ode sort 'e wun; 'e day

old Doctor Tibbetts at Cradely. A good old sort he was; he doesn't

trate yer like a panneler at nine an' a tanner a piece or whatever they treat you like a panneler at nine and a tanner a piece or whatever they gettin' a 'ear to attend to the likes o' we. 'E says, 'Jim, yo'll 'ave get a year to attend to the likes of us. 'He says, 'Jim, you'll have to knock off the beer', almost afore I'd said a waerd-well, 'e'd put me to knock off the beer, almost before I'd said a word-well, he had put me on the box an' after a time I 'ad a notice to appear at Dudley to be specially on the box and after a time I had a notice to appear at Dudley to be specially examined afore one 'o these 'ere Government doctors. I suppose they thought examined before one of these here Government doctors. I suppose they thought 
I was a-shammin'. Wen I got the notice I went to the ode doctor's surgery to ask 13

I was putting it on. When I got the notice I went to the old doctor's surgery to ask

'im wot I was to say was the matter wi' me. The ode man 'adnt tode me

him what I was to say was the matter with me. The old man hadn't told me

up to then.

up to then.

Chainmaking was an industrialised, sweatshop version of a cottage industry peculiar to the Black Country, centred upon the village of Cradley Heath. Chainmakers, both men and women, worked in sheds at the bottom of their gardens where they turned lengths of iron rod into chains, and were paid by the piece, a term derived from payment for weaving. References to being placed 'on the Staet' (on the State), 'on the box,' and 'Government doctors' place the events recounted in the narrative after 1911, but before 1948 and the introduction of the National Health Service. In 1911, the government introduced an Insurance Act which allowed workers to pay a certain amount a week into a fund so that, if they were off work ill, they would still get paid. In order to qualify for these payments, the claimant had to go before a panel of doctors to make sure that s/he was genuinely sick. The implication was clearly, that working class men and women were naturally lazy and mendacious, and their word was not to be trusted. Nationally, the usual colloquial expression for this procedure was 'going before the panel'. In the tale, 'going before the box' is a local, Black Country variation of the expression.

The extract given here is 250 words long, a third of the complete tale. It divides equally between the use of standard English and re-spellings. 125 words are written in 
standard English (50\%); 96 as allegro speech and eye dialect (38\%) and $12(20 \%)$ as dialect re-spelling. Table 1 below lists dialect re-spellings in the tale.

Table 1 Dialect Re-spellings in The Garrulous Chainmaker

\begin{tabular}{|c|c|c|}
\hline Line & $\begin{array}{l}\text { Black Country } \\
\text { MORPHOSYNTAX }\end{array}$ & gloss \\
\hline 1 & Yo’ ay & You aren’t \\
\hline 2 & Dun & Do \\
\hline 3 & I doe & I don't \\
\hline 3,4 & Yo’m & You are \\
\hline 4 & You has & You have \\
\hline 5 & on & Of \\
\hline 5 & yer & Yourself \\
\hline 6 & took & Taken \\
\hline 7 & e wun & He was \\
\hline 7 & 'e day & He did not \\
\hline 9 & o'we & of us \\
\hline 9 & they getting & they get \\
\hline \multicolumn{3}{|c|}{ PHONOLOGY } \\
\hline 1 & Goo & Go \\
\hline 3 & Waerk & Work \\
\hline 3 & Kaebles & Cables \\
\hline 6 & Staet & State \\
\hline 10 & Waerd & Word \\
\hline \multicolumn{3}{|c|}{ LEXIS } \\
\hline 4 & Drap jed & Drop dead \\
\hline 9 & Afore & Before \\
\hline 12 & Notice & Letter \\
\hline \multicolumn{3}{|c|}{ PHRASES } \\
\hline 8 & $\begin{array}{l}\text { Trate yer like a } \\
\text { paenneler at nine and } \\
\text { a tanner a piece }\end{array}$ & Treat you badly \\
\hline 11 & On the box & Off work sick \\
\hline 14 & a-shammin' & Putting it on/faking \\
\hline
\end{tabular}

It is evident that morphosyntactic differences form the largest category of dialect respellings in this tale. They are mostly to do with negative constructions, forms of the verb be and have and pronoun exchanges, all of which have been identified as distinctive of the Black Country dialect. In terms of phonology, there is the representation of pronunciations through allophones, especially the substitution of ae 
'o', $a$ ' $\mathrm{e}$ ' and $o o$ 'o'. Although such a feature can be found in other dialects of English, it has nevertheless become indexical of the Black Country dialect. Features of the dialect which appear in this particular tale, serve to reinforce and concretise the hard, manual nature of the narrator's employment, and to emphasise further the differences in lifestyle and values between the sweate doctors, teachers and parsons. Beer in this tale is a metaphor for the working man's lifeblood, and attempts by his social superiors such as doctors at regulating the amount drunk by working men such as chainmakers during visits to their surgeries, or policemen through the issuing of summons for being drunk, become symbols of oppression and means of social control. Rather than reacting with anger or rebelliousness, the chainmaker's reaction is one of irritation at the State's apparent wilful misunderstanding of his working conditions and the necessary function alcohol performs within them. Irony is used to communicate the disparity in social perspectives generally, and, in particular, the narrator's incredulousness over government bureaucracy. Elsewhere, cultural and social difference is reflected through humour, as demonstrated by the narrator's account of his assurances to the Dudley doctor during his referral examination, that it was common working practice to drink home-brewed beer and virtually abstain from the inferior substances offered in pubs. By writing the tale in dialect, the polarisation between these symbols of authority and the daily lives of the chainmakers becomes all the more marked, while the very fabric of the language becomes both the vehicle and symbol of the miscommunication which is at the heart of cultural confrontations and their comic deflation.

The brief analysis of the context within which dialect writing occurs, demonstrates firstly the linguistic distinctiveness of the Black Country dialect, particularly in terms 
of its morphosyntax and pronunciation and secondly, also exemplifies aspects of Black Country character and humour. Like Geordie writing, the intended audience for Black Country writing is primarily the local community, with both the tale's content and its inherent linguistic and literary forms acting together to reinforce the reader's awareness of the differences between parallel ways of life. In the case of The Garrulous Chainmaker, the perspectives and experiences of those who earn a living by sweated labour are contrasted with those engaged in white collar employment. The chainmaker himself would most probably have been illiterate, unaware that his speech would have been regarded as dialect outside of his social, locally dense networks of work, home and leisure, and indicative of first order indexicality and an indicator of a working class persona. However, Gough's rendition of the tale in writing, indicates third order indexicality, since Gough would have been literate and very well aware of the difference between standard English spelling and dialect re-spellings. The interplay between social and cultural values as expressed by the Chainmaker orally are doubly emphasised by the writer's decision to write down the tale in as close to an approximation of speech as possible.

The second example here is a letter written to the local newspaper, The Black Country Bugle, in late November 1995 in relation to a discussion within its letters page about grammar. As a letter, the author remains unknown. However, given the subject matter of the letter, it is safe to say that the use of Black Country features and non-standard forms generally in the letter are enregistered and indexicalised in ways which mock the ideology of linguistic 'correctness'. This letter states that:

'air wot sed Black Country tork ay the serm uz bad gramma ay fur out, 
but 'air's med one misteck (Munday, November 20). Sixty 'ear agoo,

wen we learnt English, dessimuls, un triggernomertry, un started werk

urged 14, I 'ad the kern for sayin' "bad gramma". The very term

is ungrammatickle, a thing is either gramma or it ay gramma.

Sue theer yo bin!"

That is; 'he that said Black Country talk isn't the same as bad grammar is not far out, but they've made one mistake (Monday, November 20). Sixty years ago, when we learnt English, decimals and triggernometry, and started work aged 14, I had the cane for saying "bad grammar". The very term is ungrammatical, a thing is either grammar or it is not grammar. So there you are!'

The letter is 65 words long. Its use of standard English is less than in the tale, and that of dialect re-spellings increases. 28 words are written in standard English (43\%); 21 as allegro speech and eye dialect (32\%) and $16(25 \%)$ as dialect re-spelling. Tabel 2 below summarises the dialect re-spelling.

Table 2 Dialect re-spellings in the letter

\begin{tabular}{|c|c|c|}
\hline line & Black Country & Gloss \\
\hline \multicolumn{3}{|c|}{ MORPHOSYNTAX } \\
\hline 1 & Wot & Who \\
\hline 1 & Ay & is not \\
\hline 1 & sixty ear & sixty years \\
\hline 2 & air's & she has \\
\hline 6 & Bin & Are \\
\hline \multicolumn{3}{|c|}{ PHONOLOGY } \\
\hline 1 & serm & Same \\
\hline 1 & Gramma & Grammar \\
\hline 2 & Med & Made \\
\hline
\end{tabular}




\begin{tabular}{lll}
\hline 2 & Misteck & $\begin{array}{l}\text { Mistake } \\
\text { Ago }\end{array}$ \\
2 & Agoo & Aged \\
4 & Urged & Cane \\
4 & Kern & So \\
6 & Sue & There \\
6 & Theer & You \\
2 & Yo & \\
\hline
\end{tabular}

In contrast to the tale, this letter draws upon dialect re-spelling to mark distinctive phonological and morphosyntactic features to mark Black Country identity. Such an interplay between standard and regional re-spellings, supplemented by allegro speech and eye dialect, express irony and self-deprecating mockery in this letter as much as the chainmaker did in his tale. The difference here is that the writer of the letter is all too well aware of the social stigma and 'incorrectness' attached to dialect and turns such stigma on its head. The writer deliberately mocks prevailing social attitudes towards notions of linguistic 'correctness' and its perceived superiority of standard English over all other dialects. It taps into the perennial public debate in England regarding the use of 'correct' English where anything which deviates from 'correctness' is viewed not only as an indicator of illiteracy but also degenerate behaviour (see e.g., Clark 2001, Crowley 2006).

Published some thirty years after The Garrulous Chainmaker, the letter enregisters Black Country features and indexes a Black Country place identity to a far greater degree, and, given the subject matter of the letter, can be said to do so deliberately. It is also ironic, in that the subject matter of the letter is grammar, deliberately written in non-standard English to subvert the notion of 'correctness' and that only writing in standard English is grammatically 'correct'. The pronoun exchange of 'her' in her wot 
said begins the letter, in a deliberate flouting of standard English convention of 'she'. The Black Country declension of the verb be in its positive and negative form is used, thereby bringing home the point about grammar being neither 'good' nor 'bad' by using forms that are deemed ungrammatical in standard English, but that are grammatical for the Black Country variety.

The third example is from 1997, during the construction of a roundabout at an intersection of several major roads in Dudley, the sign on approaching the construction site read:

\begin{tabular}{|c|}
\hline CASTLE GATE ISLAND \\
\hline If yowm saft enuff ter cum dahn 'ere agooin wum, your tay ull be spile't!! \\
\hline Investing in the future of Dudley Borough \\
\hline
\end{tabular}

That is, if you're daft (ie, stupid) enough to come down here on your way home, your tea (evening meal) will be spoilt. The self-deprecating, mocking, reflexive humour of this sign, as with the tale and the letter, is typical of the Black Country. Specific linguistic features distinctive of the Black Country in the sign are the use of yowm 'you are' together with spellings to reflect pronunciation, especially of vowel sounds such as dahn 'down', agooin 'going', wum 'home' and tay 'tea'. The sentence in dialect is 15 words long, of which just two, 'if', 'your', are written in standard English. (13\%); 4 as allegro speech and eye dialect (27\%) and $9(60 \%)$ as dialect respelling. Table 3 below summarises the dialect re-spelling. 


\section{Table 3 Dialect Re-spelling in the roadsign}

\begin{tabular}{|c|c|c|}
\hline line & $\begin{array}{l}\text { Black } \\
\text { Countr }\end{array}$ & gloss \\
\hline 1 & \multicolumn{2}{|c|}{ MORPHOS YNTAX } \\
\hline 1 & yo'm & you are \\
\hline \multirow[t]{2}{*}{1} & agooin & going \\
\hline & \multicolumn{2}{|c|}{ PHONOLOGY } \\
\hline 1 & dahn & down \\
\hline 1 & ere & here \\
\hline 1 & wum & home \\
\hline 1 & tay & tea \\
\hline 1 & ull & will \\
\hline 1 & spile't & spoiled \\
\hline & LEXIS & \\
\hline 1 & saft & $\begin{array}{l}\text { silly, } \\
\text { daft }\end{array}$ \\
\hline
\end{tabular}

The road sign is an example of Black Country writing written primarily for Black Country people, since it suggests that local people would be aware of the disruption caused by the construction of the roundabout, and should therefore know better than those from outside the region not to take that particular route home. As a public road sign however, it is also written for those who come from beyond the immediate area. Outsiders, those from off, and particularly if they are British, would more than likely be able to decode the message and find it amusing. Thus, the statement in dialect serves as much as an invitation to people to identify with the Black Country even if one is not of it, because at that particular moment in time, all road users, both 'insiders' and 'outsiders', are actually in it. By contrast, people from other English speaking countries or foreigners, might find it very difficult to understand, and be unable to decode part or all of it. Thus, those encountering the sign in its physical context can be placed on a cline, ranging from those people who are of the Black Country and familiar with the dialect, to members of other speech communities who 
can identify with it to those from outside the nation to whom it does not make much sense at all.

The sentence in dialect also illustrates the use of vocabulary normally associated which with the British working class. In British English, much of the vocabulary around mealtimes is socially orientated. Thus, the word 'tea' in a working class home is usually used to describe the evening meal, and the word 'supper' or 'dinner' in an upper or middle class one. However, the irony here is that the degree of literacy required on the part of the reader to both read and decode the message written in dialect cuts across such boundaries of social class. Dialect use thus highlights the gap between insiders and outsiders, but also invites the latter to decode it and thereby to bridge the gap, at least superficially. Juxtaposition of the sentence written in dialect with the standard English one: 'Investing in the future of Dudley Borough' can also be said to have both a physical and symbolic meaning. Physical meaning in the sense that the Borough is investing in the road infrastructure of the region, and symbolic in that the Borough is also investing in the maintenance of the local dialect. However, whereas 'investing in the future of Dudley Borough' denotes positive benefits for both sets of people, this notion is subverted by the sentence written in dialect which draws attention to the ways in which building the junction has caused frustrations for local people. At the same time, the inclusion of dialect in the sign alongside that of standard English points to the continued use of dialect in the region as also being an investment to the Black Country's future.

Like the other two texts, the road sign here makes use of the Black Country declension of the verb be in both present and negative forms. This grammatical 
feature is consistent across all three texts, as are the phonological variants. It is these forms then, that can be said to have been enregistered specifically as identifying features of the Black Country dialect, shown in Table 4.

Table 4. Dialect re-spelling common to all three tetxs

\begin{tabular}{|c|c|}
\hline \multirow{2}{*}{\multicolumn{2}{|c|}{$\begin{array}{l}\text { MORPHOSYNTAX } \\
\text { The Tale: }\end{array}$}} \\
\hline & \\
\hline Yo’ay & You aren't \\
\hline Yo’m & You are \\
\hline E wun & He was \\
\hline The Letter: & \\
\hline Ay & Is not \\
\hline The Sign: & \\
\hline Yo'm & You are \\
\hline PHONOLOGY & \\
\hline The tale: & \\
\hline Goo & Go \\
\hline Waerk & work \\
\hline The Letter: & \\
\hline Agoo & ago \\
\hline Werk & work \\
\hline
\end{tabular}

Texts such as the ones given above thus illustrate how regional forms formerly used unselfconsciously in speech have come to be enregistered into forms that index a Black Country identity as distinct from an identity based upon social class. The tale of The Garrulous Chainmaker, the letter and the road sign all epitomize the ironic, semiserious, self-deprecating, mocking, carnivalesque nature that characterises much of the writing in Black Country dialect. They also illustrate a shift in perception, amongst the 'in group' at least, towards the social stigma attached to a dialect such as the Black Country by 'out groups'. The writers of all three texts are well aware of such stigma but at the same time, particularly the writers of the letter and the road sign, through writing in dialect and drawing attention to the writing as dialect, poke fun at it.

\section{SUMMARY and CONCLUSIONS}


This paper has shown how conscious use of dialect in writing may not only be an intentional act, but also an act of enregisterment. It has also explored the use of dialect in social and ideological contexts in relation to a dialect of British speech, that of the Black Country. Through the analysis of three written texts taken from three different genres across a time span of thirty years, this paper has shown the particular linguistic variables upon which writers draw to enregister features of the Black Country dialect as a marker of identity linked to region and place. It has also discussed the ideological contexts within which the writing occurs, as a means of juxtaposing norms and values of those 'within' the community with those from 'outside' the community in ways which subvert traditional notions of linguistic (and social) hierarchy.

The analysis of the three examples given in this paper has explored the ways in which linguistic variability is represented in the writing of a particular speech community for and by members of that community, and also beyond its borders, real or imagined. Furthermore, they show that most people living in or connected to the area are aware of the social stigma attached to Black Country dialectic forms by those outside the community. Rather than take offence at this, the writers of the three texts considered here use specific, enregistered regional forms to perform local identity in selfconscious, ironic and mocking ways. The tale portrays the life of a worker of a particular local industry, chainmaking, that has disappeared today. The chainmaker's tale is told in such a way as to juxtapose the morals and values of middle class occupations such as parsons and doctors with those of industrial, working class occupations. There is a double irony, in that the tale was written down by someone with a middle class occupation. Dialect here can be said to give voice to the Chainmaker by a writer who is very well aware of the social stigma attached to 
variable use but of which the chainmaker himself was probably unaware. By contrast, the writers of the two more recently written texts are very well aware of stigma, but write in dialect where the very subjects of the texts - a letter in a newspaper is about the use (or misuse) of grammar, and the road sign - are ones one would not normally expect to find written in dialect. The forms which are most commonly enregistered have been found to be forms of the verb be in both its present and negative forms, and dialect re-spellings that aim to reproduce sound graphically, thereby marking their difference from standard English. It is salient to note that the verb be links to a person's very existence and by persisting in its use, Black Country writers are enregistering themselves as being from the Black Country through the very use of this linguistic construction. Thus, they show that places and dialects are essentially linked whilst also subverting the ways in which social stereotypes are represented by dialect. Furthermore, use of dialect in texts of the kind exemplified in this article often juxtaposes the norms and values of those 'outside' the community in terms of both social class and geographic distance - with those 'within' it, thereby identifying with a cultural and social normativity which may be at odds with those from 'outside' it. They do this in ways which aim to subvert ideologies of social class and linguistic 'correctness', through the use of the very phenomenon which is stigmatised: enregistered forms of the dialect itself.

\section{REFERENCES}

Adams, Michael. 2009. "Enregisterment”. American Speech 84. 2: 115-117.

Agha, A. 2007. Language and Social Relations Cambridge: Cambridge University Press. 
Anderson, B. 1991. Imagined Communities: Reflections on the origins and spread of nationalism. London: Verso.

Asprey, E. 2008. Black Country English and Black Country Identity. Unpublished Ph.D. thesis. Leeds: University of Leeds.

Beal, Joan. C. 2000. "From Geordie Ridley to Viz: Popular Literature in Tyneside English.” Language and Literature. 9. 4: 343-359.

-------- . 2005. 'Dialect Representation in Texts' in The Encyclopedia of Language and Linguistics $2^{\text {nd }}$ edn. Oxford: Elsevier Press.

-------. 2006. Language and Region London: Routledge.

--------. 2009. "Enregisterment, Commodification and Historical Context: "Geordie" versus “Sheffieldish"”'American Speech 84.2: 138-156.

Bijvoet, Ellen, and Kari Frauru. 2011. Language variation and varieties in contemporary multilingual Stockholm: an exploratory pilot study of young people's perceptions. Young Urban Swedish: Variation and change in multilingual settings, ed. Roger Källström and Inger Lindberg, 1-34. Gothenburg: University of Gothenburg.

Clark, Urszula. 2001. War Words: Language, History and the Disciplining of English Oxford: Elsevier Press. 2004. The English West Midlands in A Handbook of Varieties of English Vol 1. ed. B. Kortmann and Schneider pp 134-62. Berlin, New York Mouton de Gruyter.

-------. 2013. Language and Identity in Englishes; a sociolinguistic perspective London \& New York: Routledge.

Clark, Urszula \& Asprey, Esther 2013. Dialects of English: Birmingham and The Black Country. Edinburgh: Edinburgh University Press. 
Clarke, Sandra. 2010. Dialects of English: Newfoundland and Labrador English.

Edinburgh: Edinburgh University Press.

Cohen, A., 1985. The symbolic construction of community. Chichester: Ellis

Horwood.

Cramer, Jennifer. 2010. The Effect of Borders on the Linguistic Production and

Perception of Regional Identity in Louisville, Kentucky. Unpublished PhD thesis,

Urbana, IL: University of Illinois at Urbana-Champaign.

Coupland, N. 2007. Style: Language Variation and Identity. Cambridge: Cambridge

University Press.

---------. 2009. The mediated performance of vernaculars. Journal of English Linguistics 373 284-300.

Coupland, N. and Bishop, H. 2007. "Ideologised values for British accents." Journal of Sociolinguistics 11.1: 74-93.

Crowley, Tony 1996 Language in History London: Routledge

Crystal, David 2012. Spell it out: the singular story of English spelling. London:

Profile Books.

Dubois, Sylvie and Horvath, Barbara M. 2002. "Sounding Cajun: The Rhetorical Use of Dialect in Speech and Writing” American Speech 77.3: 264-287.

Eckert, Penelope. 2008. "Variation and the indexical field". Journal of Sociolinguistics 12:.453-76.

------------.2012. Three waves of variation study: The emergence of meaning in the study of variation. Annual Review of Anthropology, 41:87-100.

Fletcher, J.M. 1968. 'What is the Black Country? In The Blackcountryman 1.1: 1113.

Fridland, Valerie, and Kathryn Bartlett. 2006. “Correctness, Pleasantness, and Degree of Difference Ratings across Regions". American Speech 81.4: 358-386. 
Gough, T. H. 1968. 'The Garrulous Chainmaker', in H. Parsons (ed.) Black Country Stories. Dudley: Black Country Society.

Higgs, Lyndon. 2004 A Description of Grammatical Features and their Variation in the Black Country Dialect Basel: Schwabe Verlag.

Horobin, Simon. 2013. Does Spelling Matter? Oxford University Press.

Jaffe, A. 2000. Non-standard orthography and non-standard speech. Journal of Sociolinguistics 4. 4:497-513

Johnstone, Barbara, Jennifer Andrus and Andrew E. Danielson, 2006 “Mobility, Indexicality and the Enregisterment of "Pittsburghese"." In: Journal of English Linguistics 34.2:77-104.

Johnstone, Barbara. 2009. "Pittsburgh shirts: Commodification and the enregistration of an American dialect ." American Speech 84. 2: 157-75.

Labov, William. 1966. The Social Stratification of English in New York City.

Washington D.C. The Center for Applied Linguistics. 1972. Sociolinguistic Patterns. Pennsylvania: Pennsylvania

University Press.

Le Page, R.B. and Andrée Tabouret-Keller. 1987. “Acts of identity: Creole-based approaches to language and ethnicity." Language in Society 16.4:569-571

Llamas, Carmen. And Watt, Dominic. Ed. 2010. Language and Identities. Edinburgh: Edinburgh University Press.

Manley, S., 1971. The Black Country dialect in the Cradley Heath area. Unpublished M.A. dissertation. Leeds: University of Leeds.

Milroy, L. 1987. Observing and Analysing Natural Language: A Critical Account of Sociolinguistic Method. Oxford; Blackwell. 
Preston, Dennis. 1981. "Perceptual dialectology: Mental maps of United States dialects from a Hawaiian perspective". In H. Warkentyne, (ed.), Methods/Méthodes IV [Papers from the 4th International Conference on Methods in Dialectology], 19298. Victoria, B. C.: University of Victoria. 1985. 'Ritin' fowklower daun' 'rong: folklorists' failures in phonology." Journal of American Folklore 95377 304-326. 1989. Perceptual dialectology: Non-linguists' view of aerial linguistics.

Dordrecht: Foris.

------------. 2000. “Mowr and mowr bayud spellin': confessions of a sociolinguist.” Journal of Sociolinguistics 4.4: 614-21 2010. "Language, people, Salience, Space: Perceptual Dialectology and Language Regard”. Dialectoligia 5. 87-131. --.2011. “The Power of Language Regard - Discrimination, Classification, Comprehension and Production”. Dialectologia 11. 9-33.

Romanello, Maria Teresa. 2002. "The perception of urban varieties: Preliminary studies from the south of Italy". Handbook of perceptual dialectology, ed. Daniel Long and Dennis R. Preston, 329-349. Amsterdam: John Benjamins.

Silverstein, Michael. 2003. "Indexical Order and the dialectics of social life". Language and Communication. 23. 193-229.

Trudgill, Peter. 1999. Dialects of England. Blackwell Publishing. Dialects of England.

Upward and Davidson, 2011. The History of English Spelling. Oxford; WileyBlackwell.

Wells, John C. 1982. Accents of English. Cambridge: Cambridge University Press 
Williams A., and P. Kerswill, 1999. "Dialect levelling: change and continuity in Milton Keynes, Reading and Hull”. In: Foulkes, Paul and Gerald Docherty (eds) Urban Voices: Accent Studies in the British Isles. London: Arnold. 141-162.

\footnotetext{
${ }^{1}$ Thanks are due to The Leverhulme Trust for the award of a Research Fellowship RF/1/RFG/2009/0279 and to the UK Economic and Social Research Council (ESRC) for the award of a small grant RES-000-22-3744, both made in 2009 which significantly progressed data collection and baseline linguistic description summarised in this paper. Thanks are also due to Esther Asprey, my Research Associate on both projects.

${ }^{2}$ Of course, standard English is itself a dialect.

${ }^{3}$ Beal (2007) identifies a fourth category, that of regionalisms, but also admits that it is difficult to distinguish dialect re-spelling from regionalisms.

${ }^{4}$ There is no general agreement in England on the distinction between towns and cities, other than that they are larger than towns, and city status can only be granted by the British Monarch.
}

${ }^{5}$ The emphasis in all the writings in these tales is upon working men's experiences, and those of women can be said at best to be subsumed into those of men - since they often laboured equally as hard and on the same terms as men - or at worst, deemed invisible and nonexistent when it comes to talking about what it means to be of the Black Country. 